This is an Accepted Manuscript of an article published by Taylor \& Francis in [JOURNAL TITLE] on [date of publication], available online: http://www.tandfonline.com/10.1080/00074918.2014.980375. http:// authorservices.taylorandfrancis.com/sharing-your-work/ (Publisher journal website 5/9/2017)

\title{
INDONESIAN POLITICS IN 2014: DEMOCRACY'S CLOSE CALL
}

\author{
Edward Aspinall and Marcus Mietzner
}

Australian National University

ABSTRACT: Indonesian democracy experienced a near miss in 2014, when Jakarta governor Joko Widodo defeated former general Prabowo Subianto by a margin of 6.3 percent in the presidential election. Both candidates were populists who rose to prominence in the context of public disillusionment with incumbent President Yudhoyono; Prabowo, however, condemned Indonesia's current system and promised to take Indonesia in a more authoritarian direction. Though he eventually lost, his rapidly surging campaign attracted the support of almost half of the Indonesian population. We trace democracy's close call through five phases: the dying months of Yudhoyono's presidency, the rise of populist alternatives, the parliamentary elections of April 2014, the July presidential campaign, and the aftermath. We attribute Prabowo's surge to superior organisational, campaigning and financial support. Joko Widodo's victory, on the other hand, rested upon strong identification with him by poor and rural voters. Also determining the outcome was the fact that underlying public support for democracy remained strong, with Prabowo's authoritarian-populist message failing to resonate with voters. Nevertheless, democracy's future remains uncertain, given that Prabowo and his supporters now control a sufficiently large block of seats in parliament to promote a significant roll-back of key democratic reforms.

Keywords: elections, democracy, political parties, populism, presidency

Introduction

The year 2014 was an historic watershed for post-Suharto Indonesia. It marked the end of the tenyear reign of President Susilo Bambang Yudhoyono - Indonesia's first directly elected president and the first president to be democratically re-elected. Even more importantly, it was a year when Indonesian democracy missed, by a hair's breadth, experiencing a significant reversal. In the presidential election held in July, two candidates faced off: Joko Widodo, popularly known as Jokowi, represented continuity in Indonesia's democratisation; his rival, former general Prabowo Subianto espoused an authoritarian-populist message suggesting he wanted to recentralize power and dismantle key democratic institutions. In the end, Jokowi's margin of victory was a comfortable 6.3 percent, but this victory was much narrower than early opinion polls had predicted. That Prabowo came so close to winning, in a country frequently lauded as a shining example of democracy in Asia (Cochrane 2014), demands serious consideration by observers of Indonesia's politics.

In this paper we explain Indonesian democracy's near-miss by highlighting two overarching factors. The first is campaign organisation and strategy, with Prabowo running a lavishly funded and singlemindedly focused campaign that ultimately marshalled a majority of Indonesia's important parties behind him, mobilised massive oligarchic support, and allowed him to make extraordinary advances in the polls. Jokowi's campaign, in contrast, was dogged by ramshackle organisation and a difficult relationship with the main party backing him, even if he proved more adept at rousing voluntary support from ordinary citizens. The second, counteracting factor is the underlying political climate: though Indonesian citizens had many reasons to be disappointed with political, social and economic conditions - providing fertile ground for populist appeals - their disappointment was not so acute as 
to provide a groundswell favouring authoritarian reversal. Public opinion surveys showed continuing high support for democracy and even suggest that voters who opted for Prabowo also believed in democratic government.

Our account of Indonesia's 2014 flirtation with a democratic reversal proceeds through five sections. In the first, we take stock of the mixed record of the Yudhoyono presidency in its fading months. Public disappointment with his style and achievements help explain the emergence of two populist challengers (albeit populists of very different types) in the 2014 presidential race. These challengers, Jokowi and Prabowo, are introduced in the second section. The third section focuses on the parliamentary election of April 2014. Though in part framed by the looming presidential contest, the most remarkable feature of this election was that 'money politics', especially vote buying, reached dramatic new heights. A fourth section surveys the presidential campaign proper, looking at the strengths and weaknesses of both campaigns, analysing the support bases of the two candidates, and the results. In the fifth section, we describe post-election dynamics, including Prabowo's attempts to challenge the result, Jokowi's first steps to establish a new government and a move by Prabowo's coalition to abolish Indonesia's system of direct local government head elections. Overall, we conclude that while Indonesian democracy survived the presidential election of 2014 , the close outcome points to underlying sources of democratic fragility that will continue to bear influence for years to come. In particular, Prabowo's coalition in parliament has already demonstrated its capacity to erode democratic forms, and may be a significant source of pressure for democratic regression for years to come.

The twilight of the Yudhoyono presidency

President Yudhoyono had many reasons to be pleased with himself in early 2014 as he prepared to finish his second term. He had led the country through a respectable period of economic growth, avoiding the 2008 world economic crash. Indonesia had joined the G-20, and become a trillion-dollar economy. Conditions of general political stability prevailed. In many respects his had been a successful presidency. Yet the political atmosphere in the country was tinged by popular disappointment with his rule.

At the start of his second term in 2009, some observers had hoped that Yudhoyono would seize the opportunity offered by his strong electoral mandate (he achieved over 60 percent of the vote) to launch bold reforms. This was not to be; instead, the president failed to launch a single important reform program in subsequent years. In every major policy area, the report card was mixed, at best. While economic growth had been steady, and poverty had declined, in 2013 around 43 percent of the population were still living on less than US\$2 a day (see Howes and Davies 2014 for a report card on the economy). At the same time, economic inequality had increased to record heights. Infrastructure development - a major policy priority - was stalled; by the end of Yudhoyono's presidency, infrastructure spending remained below pre-crisis levels with poor roads and other transportation in particular being a major impediment to investment. The enormous energy subsidies (fuel and electricity), which soaked up \$US33 billion or 22 percent of all budget spending in 2014, remained the dragon Yudhoyono would not slay (see for example, Howes and Davies 2014: 175-178). This, in turn, 
limited the government's ability to increase spending on basic services such as education and healthcare.

As the end of Yudhoyono's time in office neared, meanwhile, his presidency became increasingly defined by what had arguably been the major political issue since early in his first term: corruption, and the fight against it spearheaded by the KPK (Corruption Eradication Commission) (Butt 2012). Though Yudhoyono had early on criticised the KPK, he eventually defended it when it was threatened by politicians and the police (McRae 2013: 299). However, during Yudhoyono's final years in office some KPK investigations started to hit close to home. This began with the arrest of the treasurer of Yudhoyono's Partai Demokrat, Muhammad Nazaruddin, in 2011 for corruption in a major construction project. The investigation led to other Demokrat figures, notably general chairperson Anas Urbaningrum, who was accused of receiving 2.2 billion rupiah from Nazaruddin and using it to buy votes during the 2010 Demokrat convention where Anas was elected party leader. Anas resigned from this position in February 2013. In defending himself, he lashed out, including by suggesting that Yudhoyono and his son, Edhi Baskoro Yudhoyono (Ibas), were also involved. Another senior Demokrat politician, Andi Mallarengeng, was charged as well, resigning as Minister of Youth and Sports in December 2012. By early 2014, Partai Demokrat was closely identified with corruption in the public mind.

Throughout 2014, the KPK continued to lay waste to the upper echelons of Indonesia's ruling elite. Anas was detained in February and subsequently tried, with testimony at his trial further implicating senior Demokrat leaders, such as DPR speaker Marzuki Alie. In September, Anas was sentenced to eight years' jail, after Andi had already been sentenced to four years in July. Suryadarma Ali, Yudhoyono's Minister for Religious Affairs and chairperson of PPP (Unity Development Party), was indicted by the KPK and had to resign from his ministerial post in May for corruption in the haj program. In September, the KPK brought corruption charges against Minister of Energy and Mineral Resources Jero Wacik, another Partai Demokrat grandee and Yudhoyono protégé, and he too stepped down. Having made much of his anti-corruption credentials in speeches at home and abroad, Yudhoyono was witnessing a welter of corruption prosecutions of senior associates as his presidency ended.

In 2009, when explaining the reasons for the president's political success, Rizal Sukma (2009: 320) observed that 'Many Indonesians admire Yudhoyono for his personal qualities, seeing him as polite, wise, fatherly, well mannered and calm.' Over the course of his second term, many came to view these features in a different light, thinking of their president as a remote figure more concerned with his own dignity and that of his family than with practical matters of government. His long-winded and self-important speeches fed a growing public image as a peragu (vacillator) who was averse to taking risks and could not make up his mind about controversial issues. Accordingly, Yudhoyono's popularity ratings slumped, dropping from 75 percent in November 2009, to 63 percent in April 2010, 57 in January 2011, 47 in June 2011, 38 in September 2011, and finally 30 percent in May 2013. His ratings recovered somewhat in 2014, as Indonesians shifted their attention to the contest over Yudhoyono's succession. They were certainly not rewarding him for any newfound enthusiasm for tough decisions: 
through 2014 President Yudhoyono seemed to embrace his lame duck status, stating he did not want to make hasty policy decisions that could be a 'time bomb' for an incoming president. ${ }^{1}$ In the dying months of his administration, for example, he baulked at a final chance to reduce fuel subsidies, despite projections that they would push the current account deficit toward 3 percent of GDP by the end of 2014. Doing so would undoubtedly have involved him in a conflict with parliament, something that he had struggled hard to avoid through his presidency.

Yudhoyono's political hesitancy also helps explain his failure to groom a viable successor from within his party. Earlier in his second term, there had been much speculation that Yudhoyono would choose a successor and promote that person to the public: Andi Mallarangeng, Coordinating Minister for Legal, Political and Security Affairs, Djoko Suyanto and even Yudhoyono's wife, Ani, were all mentioned as possibilities. Yet it eventually became clear that the president could not make up his mind, and rather than building up a potential successor he continually sought polling results on the popularity of the various candidates. Eventually, borrowing from US practice, he decided that Partai Demokrat would hold a 'convention' to choose its next presidential candidate. Once he realised that holding open elections throughout the country was prohibitively expensive, the plan was reduced to a nomination process- eleven candidates were declared in September 2013 - whose popularity would be ranked by national opinion surveys, with the most popular declared the winner. By early 2014, as the plan got into full swing, Yudhoyono and his party had already lost their cachet - and the public its interest in Partai Demokrat. Minister for state owned enterprises, Dahlan Iskan, was ultimately declared the 'winner'. But his personal popularity was too low, and when the Demokrat vote plunged in the legislative election, it became obvious the party would not field its own candidate. And so ended Yudhoyono's desultory attempts to set the agenda for his own succession.

\section{The rise of populist alternatives: Jokowi and Prabowo}

By the time the Demokrat 'convention' was underway, Jokowi and Prabowo's rise in the polls had left little room for others. Political scientists had been predicting for years that Indonesian politics was ripe for a populist challenge. A populist leader is one who claims to represent the loosely defined 'people' against elites, often claiming to have a direct, personalistic relationship with the masses (Roberts 1995; Weyland 2001). Populist leaders are especially likely to emerge when large numbers of citizens feel disenfranchised by existing political institutions, often because of economic breakdown or because official politics are seen as irredeemably corrupt. Jokowi and Prabowo certainly fit this bill as populists, but they were more than symptoms of a general malaise: part of their appeal was their contrast with Yudhoyono. In Jokowi, Indonesians found someone who possessed a popular touch that was the antithesis of Yudhoyono's wooden formality; Prabowo, on the other hand, emphasised 'firm leadership' as the antidote to Yudhoyono's hesitant style of leadership. In other words, though both contrasted with Yudhoyono, they did so in different ways: these two men were very different kinds of populists (Mietzer 2014a, 2014b).

\footnotetext{
${ }^{1}$ See for example, 'SBY: Kebijakan Ekonomi Jangan Jadi Bom Waktu Presiden Mendatang' Viva news, 30 June 2014 . At http://bisnis.news.viva.co.id/news/read/517265-sby--kebijakan-ekonomi-jangan-jadi-bom-waktu-presiden-mendatang
} 
Jokowi emerged as the frontrunner for the Indonesian presidency in 2013. He came to national prominence through a local politics route that would have been impossible during the authoritarian era. Lacking personal connections in the Suharto-era elite, Jokowi had relatively modest beginnings in the Central Java town of Solo where he also achieved success as a furniture exporter. First elected as Solo mayor in 2005, he seized national attention when he won the Jakarta gubernatorial election in September 2012 (Hamid 2014; von Lübke 2014). From this point he trended sharply upwards in opinion polls canvassing presidential candidates.

Jokowi's main selling point was his earthy personal style. In contrast to the stiff demeanour of most Indonesian officials, Jokowi had personal attributes many Indonesians could identify with: his language was informal and peppered with Javanese phrasing and pronunciation, he dressed casually, ate at roadside foodstalls, travelled economy class on airplanes, and was able to interact warmly with ordinary people. Even his face, he often joked, was 'villagey' (ndeso). One of his trademarks was his so-called blusukan - impromptu visits to marketplaces or other public places where he would chat and joke with ordinary folk, asking them about their hopes and concerns. All of this made for great television, and the national media were soon providing him with blanket - indeed, almost obsessive coverage. Accordingly, he quickly shouldered aside other presidential aspirants, most of whom were faces that had long been familiar to the public (McRae 2013: 292-294). Already two survey institutes in February 2013 placed him as the lead candidate, and one poll taken in December 2013 showed him 39 points ahead of Prabowo, at 62 to 23 percent. This was a meteoric rise, surpassing even Yudhoyono's emergence as front-runner in 2003-04.

Jokowi also had a core political program to supplement his personal appeal. This could be summed up briefly and simply: improved government services for the population. Thus, one of his signature policies in both Solo and Jakarta had been a health card program that gave residents access to free public healthcare. He had an almost technocratic interest in improving bureaucratic performance - in part by making spot checks on government workplaces, but also by cutting red tape and introducing measures such as e-procurement schemes. In the televised debates in 2014, Jokowi often said that this or that policy problem was 'easy' to fix, just needing improved government administration and willpower, giving the impression of being a leader who would pay close attention to the internal workings of government, rather than emphasising grands goals like Yudhoyono had done. Despite his obvious rapport with ordinary folk, therefore, Jokowi did not personify the angry impatience with the established order often associated with populism. He wanted to make the system work better, not replace it with something else.

Prabowo Subianto was a very different figure. Prabowo came from the very heart of the Suharto-era elite: the scion of a line of Javanese aristocrats and son of a trade minister early in Suharto's New Order regime, he had been a senior hardline general in the regime's dying years, and was married to one of Suharto's daughters (though their relationship later broke down). He also had a bad human rights record: he was dismissed from the army for his responsibility for the abduction of political activists in 1997 and 1998, some of whom never reappeared; he has also been identified as potentially responsible for major human rights violations in East Timor (van Klinken 2014). After Prabowo was 
expelled from the military in 1998, he concentrated on his business affairs, having a declared wealth of about US $\$ 147$ million in 2014 (compared to Jokowi's US $\$ 2.5$ million). The main financier of Prabowo's presidential ambitions was his younger brother, Hashim Djojohadikusumo who, like many family members of other senior officials, established a major business empire under Suharto's rule and whose net wealth was estimated by Forbes in November 2013 as about \$US700 million. ${ }^{2}$ As with many businesspeople originating from political families, the brothers' businesses are concentrated in rent-seeking parts of the economy, with a particular focus on natural resource extraction. ${ }^{3}$

After returning to Indonesia in 2004 from a period of self-imposed exile in Jordan, Prabowo set his sights single-mindedly on one goal: becoming Indonesian president. He first, in 2004, tried this luck through Golkar but then in 2008 established his own vehicle, the Gerindra (Greater Indonesia Movement) party, managing only to secure nomination as Megawati Soekarnoputri's vice presidential candidate in 2009. After that time, until the rise of Jokowi and amidst a dearth of attractive alternatives, Prabowo consistently topped polling on presidential candidates, but his support never rose significantly above 20 percent.

Prabowo's political appeal was more classically populist than Jokowi. Despite his elite pedigree, he pitched himself as an 'outsider' and a 'maverick' (Ressa 2014). In many of his campaign speeches he attacked the established political elite as corrupt and deceitful. As he told one rally: 'The Indonesian elite has lied for too long... lied to the people, lied to the nation, lied to itself', adding that 'Of fifteen people I meet in politics, fourteen of them are total liars...' (Aspinall 2014a). He directed his appeal primarily at the poor, and emphasised rural issues in his program and speeches. His campaign was also strongly nationalist: a major theme was that Indonesia was being exploited by foreigners who were sucking out the country's natural riches, leading to impoverishment of its people. His campaign appearances had a highly theatrical character, with lots of uniforms, marching, and fiery oratory, and with much of the styling obviously based on Sukarno and other nationalist leaders from the 1940s, 1950s and 1960s (Aspinall 2014a, Mietzner 2014a, 2014b).

Prabowo's love of grand display resonated with his strongest message: in order to overcome its multiple problems Indonesia needed strong leadership, leadership that only he could provide. His stress on leadership resonated with explicitly authoritarian elements in his program: the Gerindra party platform stated Indonesia should return to the president-centred authoritarian 1945 Constitution, while late in the campaign he publicly mused on the need for the country to do away with direct elections of executive government leaders - which he described as a Western product inappropriate for Indonesia, and which were akin to a bad habit such as smoking (Aspinall and Mietzner 2014a). He also possessed a combustible personality, was known for using physical violence against subordinates, and sometimes became aroused to an almost hysterical pitch in campaign speeches, especially when attacking unidentified 'traitors' who wanted to betray the nation and steal the election from him. These

${ }^{2}$ http://www.forbes.com/profile/hashim-djojohadikusumo/ Accessed 5 October 2014.

3 'Hashim Djojohadikusumo Returns to Indonesia After a post-Suharto Exile', Forbes Asia, 18 January 2010. 
were all warning signs that Indonesia would likely head in a more authoritarian election should he be elected, despite Prabowo's frequent pleas that he was a 'democrat'.

Prabowo's pitch was typical of the sort of appeal that might resonate in a country with a large mass of poor voters who feel economically disadvantaged and alienated from established elites and institutions. As we have seen, Indonesians had plenty to be discontented with as the Yudhoyono presidency drew to a close. However, there were limits to this discontent. Indonesia was not a democracy in crisis, or even in decline. The economy remained relatively strong and, despite disillusionment with Yudhoyono and corruption, support for democracy was robust. For example, in three SMRC polls conducted between April 2013 and 2014, an average of 74 percent of respondents expressed preference for democratic over dictatorial government (with most of the remainder failing to understand the question). Satisfaction with the functioning of democracy fluctuated more widely but has been generally positive over the last decade, and was trending upward from late 2012 (see figure 1). Importantly, Indonesians' satisfaction with the incumbent democratic regime tends to be highest during election times, and that was true in 2014 as well. As Indonesia's election period began, therefore, there were few signs of a groundswell of support for a radical replacement of the existing political framework. As we shall argue, this fact played a major role in shaping the eventual outcome of the presidential poll. 


\section{Trend Kepuasan terhadap Demokrasi (\%)}

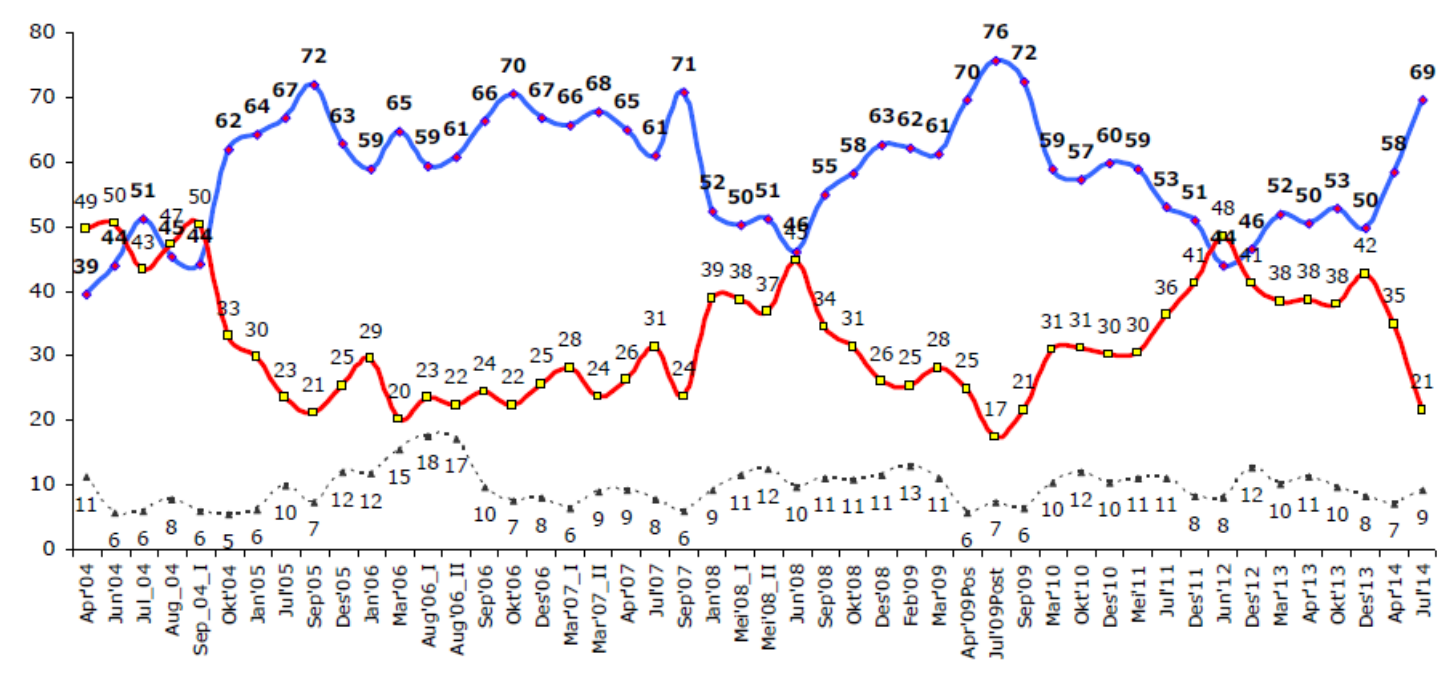

$\Longrightarrow$ Puas + Sangat puas $\quad \square$ Tidak puas + Sangat tidak puas $\quad \ldots \ldots$ TT / T J

$\frac{\text { SAIFULMUJANI }}{\text { reseatens consulting }}$

Figure 1

The legislative elections

Indonesia's fourth post-Suharto parliamentary elections were held on 9 April 2014. As in the past, candidates were running for seats in the 560-member DPR, as well as in DPRDs (Regional People's Representative Councils) in the 34 provinces and 498 districts and cities. The number of parties was reduced compared to previous elections, as a result of tougher registration requirements (parties were required to have representation in all provinces, for example). Although only 12 parties (compared to 38 in 2009) fielded candidates (plus an additional three local parties in Aceh), the fact that candidates were standing in multi-member districts still meant that the election was immense, with an estimated 180,000 candidates and 186 million registered voters. 


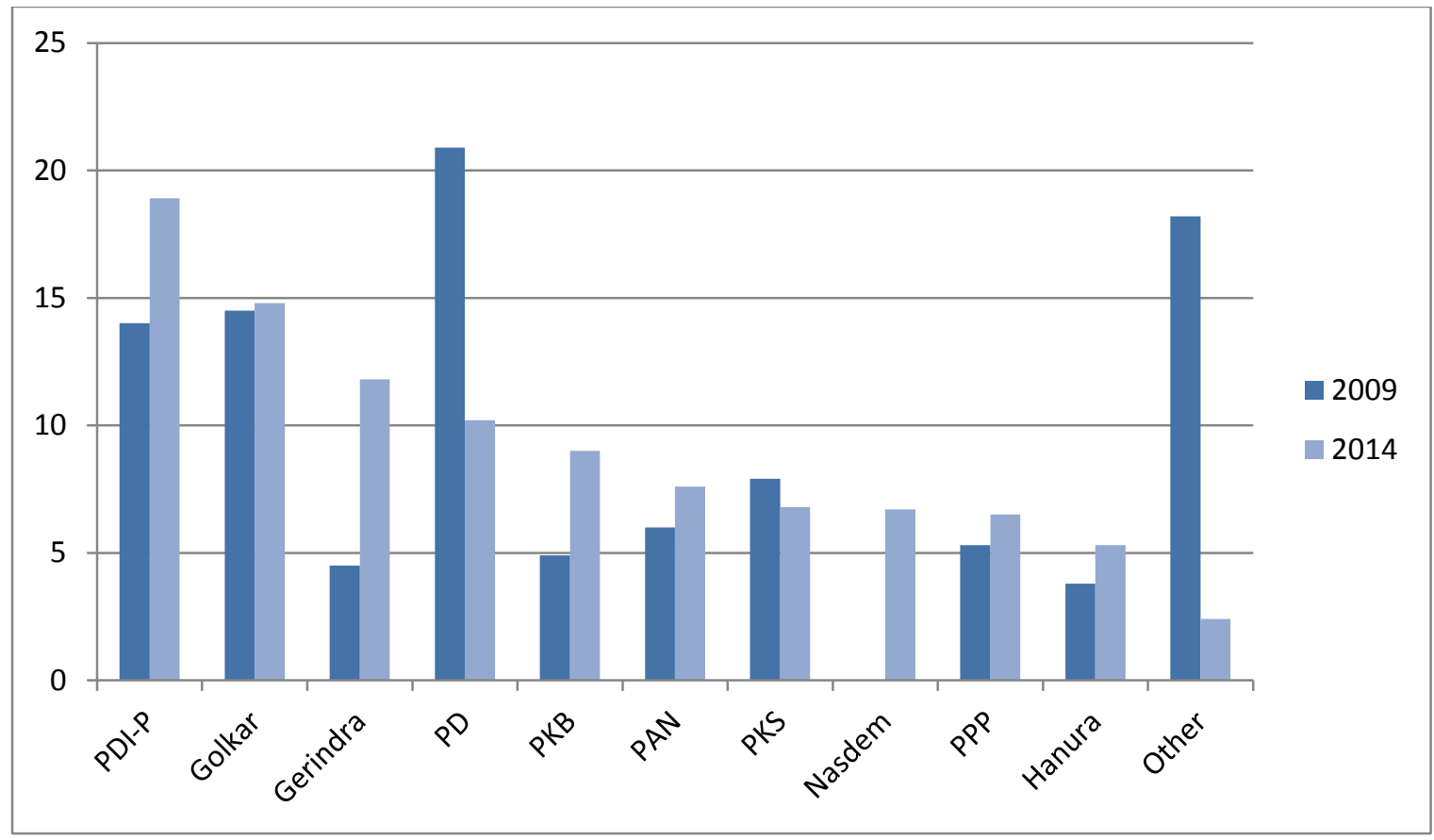

Figure 2: DPR election results, 2009 and 2014

The results at the national level (see figure 2) showed a relatively evenly splintered party map. The fact that only two micro-parties were able to run this year provided a boost to the surviving parties and only two parties suffered a decline. The biggest loser was Yudhoyono's Partai Demokrat which, for reasons canvassed above, dropped from first place in 2009 with 20.9 percent of the vote to fourth place with 10.2 percent. PDI-P moved into first place with 18.9 percent, a position it had not held since 1999, as a result of the 'Jokowi effect' (although that effect was not as strong as initially anticipated). An even bigger winner, however, was Gerindra, Prabowo's party, which more than doubled its vote share from 4.5 to 11.8 percent. Nasdem, a new party established by media tycoon Surya Paloh, also garnered a respectable 6.7 percent.

Overall, the election confirmed trends that had emerged in previous elections, rather than establishing new ones. The Islamic-based parties slightly improved on their performance in 2009, with 31.4 percent of the vote, up from 29 percent in 2009. The growing importance of 'presidentialist' parties (Demokrat, Nasdem, Hanura, and Gerindra) - parties which were established to further the ambitions of an individual politician - was confirmed, with their combined vote increasing from 30 to 34 percent. So too was the increasingly even distribution of party strength: if in the first post-Suharto election in 1999 six parties had garnered over 5 percent of the vote, in 2014 there were ten; in 1999 the two largest parties (PDI-P and Golkar) gained over half the vote between them, in 2014 they got only a third. 
Perhaps the most striking feature of the election, however, was the growing importance of vote buying or 'money politics', which was more flagrant than in previous elections. ${ }^{4}$ Throughout the country, candidates provided gifts of various sorts to their constituents. Often these took the form of donations for the collective benefit of a community (repairs to a road or irrigation channel, or uniforms and equipment for a prayer group or sports club, for example). Many candidates distributed goods, such as clothing, foodstuffs, or basic household items, to individual voters. Outright vote buying - known in Indonesian by the term serangan fajar, or the 'dawn attack' - was also far more widespread than in the past, with candidates in many places organising huge teams of vote brokers to distribute cash payments to voters in the days leading to the poll. To observers throughout the country, the trend was obvious. As one member of an election monitoring network put it: "It's now completely open... The money politics trend is increasingly vulgar. And the vulgarity is getting worse.' (Kompas, 13 April 2014).

This aspect of the election was largely a by-product of the open-list Proportional Representation (PR) electoral system adopted in Indonesia just before the 2009 election. Under this system, voters choose to vote either for a party or an individual candidate. The votes for each party and all its individual candidates are then combined to determine if that party has won one or more seats in the electoral district concerned. Subsequently, the seat or seats won by a party are allocated to that party's candidate with the highest number of personal votes. This system provides candidates with a strong incentive to build their personal campaigns, rather than promote their party. It often means the main axis of competition is between individual candidates within a single party, rather than between parties.

Not surprisingly, therefore, 2014 witnessed the entrenchment of a pattern of personalised campaigning that first became evident in 2009. Many candidates, rather than relying on party machines, constructed personal 'success teams' to connect them to voters. Vote buying was part of this trend: candidates were investing their own money (or that of personal donors) to ensure that they achieved individual success. In the long term, this pattern will erode the role of parties, programs and ideology in national politics. In 2014 it also was arguably a factor - though not a major one - contributing to a political climate conducive to populist appeals. Certainly, the ubiquity of vote buying added force to Prabowo's claims about the corruption of the political class. He told voters: 'You should take the money because it is your own money. The people's money that has been lost to corruption. But, take that money and still vote for Gerindra' (Triyoga 2014). Of course, Gerindra candidates were just as guilty of vote buying as anyone else.

At the same time, the legislative election showed that party identity was far from irrelevant: the decline in the Demokrat vote, as well as the rise of Gerindra and the less dramatic increase for PDI-P suggested that some voters still took national trends and leaders into account when casting their

\footnotetext{
${ }^{4}$ In the months leading to the 9 April legislative election one of the authors (Aspinall) travelled through fourteen provinces and interviewed about 100 candidates for legislative office as part of a large research project on 'money politics' run in conjunction with the University of Gadjah Mada. As part of this project, 50 researchers were located in 20 provinces, interviewing a total of about 1,500 legislative candidates and campaign workers. It was the near-unanimous view of all the candidates interviewed by Aspinall, and of the researchers engaged in the project after they concluded the fieldwork, that vote buying was more intense in 2014 compared to 2009 and earlier elections. This greater intensity was evident in the proportion of candidates who engaged in the practice, the sums distributed to individual voters and communities, and total expenditures on the practice by contestants. For elaboration see Aspinall 2014b.
} 
ballots. And, to a large degree, the legislative election was overshadowed by preparations for the looming presidential contest. In particular, much attention focused on Jokowi, already established as the favourite by this time.

Through the second part of 2013 and early 2014, much public speculation had centered on which party or parties would nominate Jokowi as their presidential candidate. Though Jokowi had been a member of the PDI-P for some time, and the party had nominated him as both Solo mayor and Jakarta governor, he owed his political success above all to his personal reputation and was not identified as being a committed PDI-P cadre. Accordingly, for many months, there was much 'will-she-won't-she' guesswork on whether PDI-P leader and former president Megawati Sukarnoputri would endorse Jokowi or stand again for the presidency herself (perhaps taking Jokowi as her running mate). The problem was solved in part by the polling figures that placed Jokowi in a dominant position: for example, an SMRC survey in mid-December 2013 showed that 46 percent of voters chose Jokowi when confronted by a choice between him and Megawati, with only 21 percent preferring the latter. But it also took a concerted effort by Jokowi through 2013 to convince Megawati of his loyalty to PDI-P as a party and to her personally. This effort was successful and he was announced as the PDIP's presidential candidate on 14 March, a mere three weeks before the legislative vote (for a more detailed account, see Mietzner 2104b). The problem, however, was that in order to secure the nomination, Jokowi had to demonstrate loyalty to the PDI-P and Megawati in ways that could seem craven to persons outside the party: for instance, by kissing Megawati's hand in public. This opened what would become perhaps Jokowi's greatest vulnerability in ensuing months: the accusation - which became central to the negative campaign waged against him - that he was a 'puppet candidate' (calon boneka), with Megawati pulling the strings.

Throughout the legislative campaign, problems in the internal organisation of Jokowi's campaign also became evident. The major difficulty was his problematic relationship with the PDI-P, where he had many backers, but where his rise also threatened entrenched interests. A key recalcitrant was Megawati's daughter, Puan Maharani, who had a strong sense of entitlement in a party based on her family and the myth of her grandfather, Indonesia's founding president Sukarno (Mietzner 2012). Accordingly, Puan, who was in charge of the PDI-P electoral success board, resented her sidelining by Jokowi. Even after his candidacy was announced she refused to change the party's advertising strategy, and continued to run national television advertisements that featured herself in the leading role. Jokowi suggested early on that the campaign needed to highlight him in order to boost both the PDI-P vote and his personal popularity. Puan, however, acceded to this request only very late in the piece - and party officials close to Jokowi had to collect money privately in order to pay for new advertisements (Mietzner 2014b).

Other problems, however, also began to emerge, including a multiplication of poorly coordinated teams running the campaign, as well as questions about whether Jokowi's blusukan-style of campaigning based on direct interaction with voters would be adequate for a national election in a country of a quarter of a billion people. At the same time, Prabowo and his campaign showed every sign of being highly disciplined and effective, with relentless media advertising and set-piece mass 
rallies all stressing a simple message: Prabowo was the man Indonesia needed to lead it toward a desperately needed national renaissance.

The results were clear. Though the PDI-P experienced a boost compared to 2009, it did not achieve the 25 percent that early polls suggested might be possible, let alone the higher results that Jokowi and party leaders had hoped for. In the presidential stakes, too, the ground was shifting. In a poll taken by the Indikator institute at the start of the legislative campaign in March, Jokowi was at 56 percent against Prabowo's 20 percent (Indikator Politik Indonesia 2014a: 40). On voting day, April 9, SRMC exit polls discovered that only 43 percent of voters would have opted for Jokowi, and 27 for Prabowo (SMRC 2014b: 28). The gap was narrowing rapidly. Hence, the parliamentary election ended with signs that Jokowi's juggernaut was faltering, and Prabowo was on the rise.

\section{The presidential contest}

Soon after the legislative ballot was over, negotiations over presidential coalitions began. Based on existing rules, the right to nominate presidential candidates was limited to parties or party coalitions that received 20 percent of the seats or 25 percent of the votes in the preceding parliamentary poll. As expected, only the two leading candidates, Jokowi and Prabowo, were able to build coalitions strong enough to pass this nomination threshold. During the negotiations with party leaders, the two nominees showed fundamentally different (and rather surprising) approaches. Jokowi, the more moderate and soft-spoken of the two men, adopted a hard-line paradigm, according to which he would not cut any power-sharing deals. "I don't want to be held hostage by parties, so we only work with partners that pose no conditions for their cooperation", Jokowi stated repeatedly. ${ }^{5}$ Put off by this uncompromising stance, major parties such as Golkar, PPP and PAN - which were initially inclined to support Jokowi - decided to stay away from Jokowi's coalition. Eventually, that coalition included PDI-P, the traditionalist Muslim party PKB, Surya Paloh's Nasdem, and Hanura, the party led by former armed forces commander Wiranto. Together, these parties held 37 percent of parliamentary seats in the parliament that would be sworn in October. By entering the Jokowi alliance, they all agreed not to demand cabinet seats or other concessions from Jokowi - although there was an implicit understanding that such rewards would be forthcoming should Jokowi prevail. After an intensive search, former vice-president Jusuf Kalla, a Golkar cadre, was announced as Jokowi's running mate reportedly at the strong insistence of Megawati.

In contrast to Jokowi, Prabowo engaged ardently in pre-election power-sharing agreements, offering cabinet seats and significant resources to parties should he be nominated and elected. This practice sat oddly with his populist speeches, which passionately condemned political horse-trading as a source of Indonesia's alleged decay. When he had completed his negotiations, Prabowo - who promised to free Indonesia from the plague of corruption - had secured the support of PKS, whose former president had been sentenced in December 2013 to 16 years in prison for corruption; PPP, whose chairman was indicated for corruption and had to resign as Minister of Religious Affairs shortly before

\footnotetext{
${ }^{5}$ Jokowi at a meeting with volunteers, Bogor, 7 June 2014, notes by Marcus Mietzner.
} 
the election campaign began; Golkar, whose tycoon chairman Abdurizal Bakrie was known for series of questionable business deals; and PAN, whose chairman Hatta Rajasa was reportedly supported by oil import magnate Muhammad Riza Chalid, and who promised to shoulder a large proportion of the campaign costs in exchange for becoming Prabowo's running mate. Yudhoyono's Partai Demokrat also subsequently joined the coalition, although Yudhoyono himself tried to avoid an unambiguous endorsement of Prabowo. Named the Red-and-White Coalition, Prabowo's alliance controlled 63 percent of the seats in the coming parliament.

The two candidates also had diametrically opposed campaign styles. As during the parliamentary elections, Jokowi's presidential campaign was marked by organisational chaos, absence of a clear message, conflicts with PDI-P, and funding problems. Pushing himself to the brink of exhaustion, Jokowi toured Java in a convoy of cars, arriving hours late to most events and cancelling others on short notice. In his speeches, he often struck up conversations about day-to-day life with the audience rather than discussing ideas about where he wanted to take Indonesia. While this proved popular with rural voters, the media and many town dwellers were left with the impression that Jokowi had no clear concepts about how he wanted to govern (though his campaign team had drafted a relatively comprehensive platform document). The idea of a supposedly urgent "mental revolution" was hastily drafted to conceal this lack of a central idea, but it left most commentators unimpressed. Meanwhile, Puan Maharani - who controlled a large proportion of the campaign funds - continued her tacit rivalry with Jokowi, reluctantly transferring only small sums to the candidate. Many PDI-P offices around the country felt that they lacked the resources to run a full-fledged campaign, having just spent most of their money on the legislative elections. As a result, Jokowi called on ordinary citizens to donate to his campaign (he collected Rp 37.5 billion, or around US\$ 3.1 million) (Snyder 2014), and he mobilized non-party volunteers to take the lead in areas where PDI-P was absent or weak.

Prabowo's campaign, on the other hand, was a classic example of oligarchic machine politics. Funded by his brother, Hatta's backers and his own wealth, Prabowo flew in his private jet to a small but carefully selected number of campaign spots. Prabowo allies on the ground mobilized networks of Islamic clerics, church officials, local bureaucrats and other influential community leaders, offering them money in the hope that they would order their followers to vote for Prabowo. ${ }^{2}$ Prabowo's coalition partners also activated their party machines, apparently to considerable effect. While at the beginning of the campaign many sympathizers of pro-Prabowo parties had stated their intention to vote for Jokowi, shortly before voting day the majority of party supporters had fallen into line: 81 percent of PKS voters pledged to back Prabowo (up from 53 percent two weeks earlier), as did 56 percent of Golkar voters (up from 43 percent), and 50 percent of Democratic Party voters (up from 37 percent) (Indo Barometer 2014a: 34; and 2014b: 24). In addition, Prabowo also enjoyed the support of conservative Islamic militias and youth gangs notorious for their violent and predatory behaviour (Rinaldi 2014). While unpopular with some voters, the militias provided a suitable backdrop for Prabowo's strongman rhetoric, which he delivered powerfully at each campaign event. Portraying Indonesia as a country close to collapse, Prabowo offered himself as the saviour who would rescue

\footnotetext{
${ }^{6}$ Interview by the authors with pro-Prabowo operators in Madiun, East Java, 28 June 2014.
} 
Indonesia from corruption and foreign exploitation. Prabowo's message was consistent and memorable, effectively highlighting Jokowi's lack of a platform.

Prabowo's populist and ultranationalist campaign oratory was complemented by a highly effective anti-Jokowi smear campaign. While earlier attacks on Jokowi's alleged dependency on Megawati had raised a legitimate political issue, pro-Prabowo ground troops began to spread false rumours in early May that Jokowi was the son of a Singaporean Christian. Initially laughed off as a joke, the misinformation spread throughout Indonesia. Said one member of Jokowi's campaign team, "it was unbelievable - when we came to North Sulawesi, a predominantly Christian area, some people said 'great that we finally have a Christian president". 7 The rumour became so widespread that Jokowi decided to counter it personally during almost all of his campaign appearances. Whereas some of his supporters believed that this move helped to mitigate the impact of the smear campaign, others thought that Jokowi in fact helped his detractors to keep the issue alive. In any case, with Jokowi spending much of his time on defending himself against fabrications, he was unable to define his own campaign agenda. Instead, his opponents defined it for him.

It was not surprising, then, that the gap between Jokowi and Prabowo continued to narrow. In May, as the pairs of candidates registered their candidacies, a SMRC poll found that 48 percent of respondents supported Jokowi, while 39 percent backed Prabowo (SMRC 2014c: 13). In early June, the result was 48 to 42 , and in mid-June, the margin between two candidates was within the margin of error: 47 to 45 percent. In other words, since December 2013, Jokowi had lost 15 percent support while Prabowo had gained 22. In fact, a number of independent pollsters had Prabowo ahead by the third week of June, leading to panic in the Jokowi camp and horror among the liberal segment of Indonesia's middle class about the increasingly likely prospect of a Prabowo presidency.

But the polls not only revealed that the margin between Jokowi and Prabowo had all but evaporated; they also showed surprising demographic patterns in the candidates' core constituencies. Prabowo, the populist, who - like his Thai role model Thaksin Shinawatra - had mainly appealed to the rural poor for support, instead was strongest among the urban middle class. Jokowi, on the other hand, who as mayor of Solo and governor of Jakarta had become known as a competent manager of urban development issues, was primarily supported by the rural poor. An exit poll, taken on the day of the presidential election, established that Prabowo trailed Jokowi by 39 to 47 percent in the segment of voters with elementary school degrees - but led Jokowi by 46 to 34 percent among university graduates (Indikator Politik Indonesia 2014b: 21-22). Similarly, Prabowo was behind Jokowi by 37 to 47 percent among voters with an income of below Rp 1 million (US\$ 83), but led him by 45 to 39 percent in the higher-income bracket (above Rp. 2 million, or US\$167). Prabowo also trailed in rural areas, by 38 to 47 percent, while leading in cities by 42 to 40 percent. Apparently, Jokowi - despite his role as a city administrator - dominated the lower-class constituency that identified with his humble origins in the countryside of Java, while Prabowo attracted the majority within his own class segment, the educated middle and upper classes.

\footnotetext{
${ }^{7}$ Interview by Marcus Mietzner, Jakarta, 20 June 2014.
} 
Believing that he was now ahead but needed to strengthen his support base among the poor, Prabowo held a mass rally in Jakarta's Gelora Bung Karno stadium on 22 June. A similar event during the parliamentary campaign in March had attracted worldwide attention, with Prabowo flying in by helicopter and reviewing a parade of his private militias on a white military-style horse. This time, there were no horses, but he tried to mobilise the lower classes by portraying himself as being one of them. Prabowo, who had been brought up in elite schools abroad and enjoyed all the privileges associated with being a member of an Indonesian elite family, suddenly proclaimed that "those people who say I was always rich are lying; I was once poor like you, my brothers and sisters - I had to think about how to be able to buy something to eat next week". Typical of its shambolic organisation, Jokowi's campaign machine did not expose this obvious fabrication or highlight the broader mismatch between Prabowo's rhetoric and his personal biography.

However, Prabowo's advance suddenly stopped. After three months of continuous decline, Jokowi registered a one-percent rise in a SMRC survey taken in early July, and Prabowo's numbers stagnated for the first time since April. According to a Jokowi campaign adviser, "there is no other way to explain this: this was divine intervention - everything was going against us, and then came this bounce out of nowhere." Indeed, it may be difficult to scientifically explain the abrupt turnaround in the polls, but four factors appear to have played a role. First, Prabowo made a major strategic mistake in the final phase of the campaign. Previously, he had been very careful not to reveal too much about his plans for political change, issuing only vague assurances that he was a "democrat". In late June, however, he declared off-the-cuff that direct elections were not in line with Indonesian culture, and he suggested that a "new consensus" was needed - using formulations Suharto had applied in the late 1960s when justifying the establishment of his repressive New Order regime (Aspinall and Mietzner 2014). Although Jokowi again failed to capitalise on Prabowo's unintended display of neo-authoritarian thought, some media outlets critically analysed Prabowo's statement. Getting nervous, Prabowo felt compelled to defend himself on Facebook, claiming that he was falsely depicted as a "dictator".

The second factor in Jokowi's recovery related to processes of electoral decision-making among swing and undecided voters. Crucially, the renewed focus on Prabowo's commitment to democracy coincided with the last period of the campaign, in which voters usually reflect on their long-term political attitudes and have a fresh, critical look at their choice. As indicated above, a key segment of the Prabowo electorate consisted of the 15 percent of Jokowi supporters that had turned their back on him since December 2013 (and particularly after March 2014). Arguably, they had shifted to Prabowo largely out of disappointment with Jokowi's poor performance in the campaign, and because they liked Prabowo's bold style, not because they were fanatic Prabowo loyalists or endorsed his antidemocratic agenda. As Prabowo's numbers continued to rise, however, a small but not insignificant number of these voters appeared to have become uncomfortable with their choice and switched backed to Jokowi. In part, this switch was driven by the satisfaction of voters with the incumbent democratic system, which reached a three-year high during the elections and contrasted sharply with

\footnotetext{
${ }^{8}$ Notes by Marcus Mietzner, Jakarta, 22 June 2014.

${ }^{9}$ Interview by Marcus Mietzner, Jakarta9 September 2014.
} 
Prabowo's oft-repeated claim of democracy's decay. The same dynamics affected undecided voters, who all seemed to move Jokowi's way.

The solidity of Jokowi's core constituency offers the third explanation for his ability to arrest his decline and bounce back. While Jokowi's support had fallen gradually over several months, it never dropped below 47 percent, and thus always remained within striking distance of victory. This meant that Jokowi could build on a much stronger support base of loyal, long-term voters than Prabowo, whose electorate had increased from a nucleus of 20 percent to 45 percent in a matter of weeks. Consequently, more than half of Prabowo's electorate had to be categorised as "soft voters" - a fact the Prabowo camp was acutely aware of. The campaign's chief pollster in East Java predicted in late June that Jokowi would win the election because his voters were much more committed than Prabowo's. ${ }^{10}$ This commitment, he continued, would show especially in a higher turnout of Jokowi voters. In addition to the rural poor, Jokowi's electorate consisted disproportionately of women, many of who were put off by Prabowo's belligerent rhetoric and reputation for violent outbursts.

Fourth, Jokowi's late "surge" was also reinforced by his strong showing in the final week of the campaign. After months of mishaps, chaotic planning and aimless struggles to find a message, Jokowi ultimately seemed to a have found his identity as a campaigner. On the last Saturday before the election, he attended a large concert in Jakarta at which some of Indonesia's most famous rock bands played for him. Said one of his aides, "this was a critical moment; we knew that if the papers carried the pictures of this event on their front pages the next day, it would give Jokowi a big boost". ${ }^{11}$ And indeed, a bird's-eye-view picture of Jokowi standing in the centre of the stadium amidst his followers became the most iconic picture of the campaign. On the same evening, Jokowi performed strongly in the last of the four televised presidential debates with Prabowo, while the latter appeared irritated, aggressive and confused. It later emerged that Jokowi supporters in the studio had provoked Prabowo during the commercial breaks by shouting references to his dark human rights history.

As it turned out, Jokowi managed to sustain his boost until election day - he won the contest against Prabowo with 53.15 percent against Prabowo's 46.85. In the end, it was a more comfortable victory than the last polls had indicated. Jokowi and Kalla won in 24 provinces (including the overseas constituency), with Jokowi mainly responsible for securing victory in Central and East Java while Kalla succeeded in capturing all of his home island Sulawesi except Gorontalo (see map 1). Prabowo and Hatta, on the other hand, took 10 provinces, with its most important prizes West Java and four provinces on Hatta's home turf of Sumatra. Jokowi's was a victory of promises of governance reform over populist ideas of returning Indonesia to its pre-democratic "glory"; of improvised campaign chaos over machine politics; and of pragmatic notions of engaging with the world over radical rhetoric of Indonesia's continued enslavement by foreign forces. But those who had studied Prabowo intensively knew that he would not go quietly - and he did not disappoint.

Election aftermath and the new government

\footnotetext{
${ }^{10}$ Interview by the authors, Surabaya, 27 June 2014.

${ }^{11}$ Interview by Marcus Mietzner, Jakarta, 9 September 2014.
} 
Prior to the election, most discussions among Indonesia watchers had focused on the question of whether Prabowo's candidacy constituted a real threat to Indonesian democracy. Some observers, including the authors, believed that Prabowo's character, his history, his populist rhetoric and his policy platform indicated that if elected he would try to fundamentally revamp Indonesia's democratic polity. By contrast, many others (including diplomats and foreign journalists) interpreted Prabowo's bellicose rhetoric as nothing more than a clever campaign strategy, trusting that he would turn out to be the pragmatist he had presented himself as being in private meetings with foreign business actors. Clearly, a significant number of voters endorsed this latter view. Post-election polls showed that support for democracy stood at 79 percent among Prabowo voters (SMRC 2014a: 23), indicating that they were not convinced Prabowo would dismantle Indonesia's democratic structures. It appears, then, that many voters did not interpret a vote for Prabowo as a vote against democracy; the aftermath of the election, however, delivered much evidence of Prabowo's anti-democratic attitude and intentions.

To begin with, Prabowo and his team used manipulated quick counts to avoid conceding defeat and, indeed, they even claimed victory in the election. On the day of the ballot, all credible survey institutes had declared Jokowi the winner of the contest, each using quick count data based on a sample of around 2,000 polling stations across Indonesia. This method had been used in hundreds of elections at the national and local level since 2004, and had proven highly accurate. Thus, there was no doubt that Jokowi had prevailed. However, four survey institutes associated with or funded by Prabowo and his allies issued quick counts that showed Prabowo as the winner. The four institutes had very questionable reputations - or, in one case, no reputation at all (Aspinall and Mietzner 2014b). When the professional association of opinion pollsters wanted to audit two of the institutes (the other two weren't members), they refused and were subsequently expelled. On 22 July, the KPU (General Elections Commission) announced the official results, which were very close to the quick counts that had seen Jokowi as the winner on 9 July. Prabowo's willingness to fabricate election data - and have it published on television stations owned by his associates - gave clear indications of how he would have managed elections potentially held under his watch as president.

Although Prabowo's manoeuvre was transparent to close observers of Indonesia's opinion polling community, it was very effective with the media and other segments of society. Even many foreign news outlets changed their reporting from "Jokowi victory" to "disputed election". Behind this smokescreen of fake quick counts and declarations of victory, Prabowo's team had won the time necessary to intervene in the official KPU count. In Indonesian elections, data travels through multiple levels from the polling station to villages, sub-districts, districts and provinces before arriving at the KPU in Jakarta. At all of these levels, manipulations can occur, with numbers changed manually before being sent on. The 2014 presidential elections were no exception, with most manipulations carried out by Prabowo associates (Jong 2014). But there was one big difference between previous polls and the 2014 ballot: the KPU had decided to upload all forms, from all levels, to its website, making it possible for citizens to check whether data was changed as it made its way to the centre. Using these documents, internet activists developed software that tabulated the results nationwide, highlighting cases where 
data was inconsistent. Consequently, manipulations were quickly identified and followed up by the KPU, neutralising the attempts by the Prabowo team to alter the outcome.

Having been declared the loser of the election, Prabowo subsequently shifted his focus to challenging its outcome in the Constitutional Court. While claiming that systematic fraud had cheated him out of becoming president, Prabowo mobilised his supporters to demonstrate at the Court and intimidate its judges. In a video posted online, he likened his struggle to the battle of Surabaya in 1945, when proindependence groups had resisted a British request to surrender their weapons. ${ }^{12}$ On 21 August, the day of the Court's verdict, thousands of thugs - supported by paramilitary trucks - tried to break through the police barricade at the Court. Presumably, their goal was to abort the reading of the judgment, which was underway at the time of the attack. However, the police managed to keep the violent demonstrators from entering the building. As had been widely expected, the judges rejected Prabowo's complaint, unanimously stating that he had failed to present any evidence for his claims. Rather than conceding the election, however, Prabowo went to visit the injured attackers of the Court in hospital.

Prabowo's anti-democratic disposition became further apparent when he led his Red-and-White Coalition to push for the abolition of direct elections of governors, mayors and district heads. A new law on local elections had been deliberated by parliament since 2012, but the government and most factions had agreed in late 2013 to leave the existing regime of direct elections in place. After Prabowo's election loss, however, the parties associated with the Coalition abruptly changed their stance: in early September, they proposed that local government heads should be elected by their legislatures, as had been the case under the New Order and in the early post-authoritarian transition between 1998 and 2004. Through this change, Prabowo's allies hoped, the Coalition would win the vast majority of top executive posts in the regions. Said one leading Coalition politician, "we let Jokowi be president, but we'll rule Indonesia at the grassroots". ${ }^{13}$ Many local government heads protested against this move, as did pro-democracy groups and the media. For them, returning local elections to their pre-democratic framework was equivalent to a substantive regression of Indonesian democracy itself. Even so, on September 25 the DPR passed the new law eliminating direct elections by a vote of 226 to 135. Though Yudhoyono had earlier stated his support for direct elections, he failed to direct his Partai Demokrat to resist the change and they walked out of the session - swinging the numbers to the Red-and-White Coalition and making Yudhoyono himself complicit in a major act of democratic regression.

One of the main reasons for Prabowo's ability to maintain the Red-and-White Coalition for his postelection operations was Jokowi's refusal to change his no-deals approach to coalition building. Several parties in Prabowo's coalition had approached Jokowi after the announcement of the election result to evaluate the possibility of them gaining entry into the new government alliance. But Jokowi's answer was the same as during the pre-election negotiations in May: they were welcome to join, but should

\footnotetext{
12 The video can be seen at http://www.youtube.com/watch?v=S9pfcbCzprU.

${ }^{13}$ Interview by Marcus Mietzner, Jakarta, 11 September 2014.
} 
not demand or expect any concessions. ${ }^{14}$ Disappointed at that reply, these parties decided to stay with Prabowo - for the time being at least. Prabowo promised them senior posts in parliament if they stuck together as a coalition, and for many, this appeared as an attractive option. ${ }^{15}$ Jokowi, however, was unmoved by the fact that his post-election coalition did not expand in the way many observers had predicted. Convinced that he could rule even with a minority in parliament, Jokowi focused on the technical preparations for his inauguration on 20 October. ${ }^{16} \mathrm{~A}$ transition team was put in place (modelled along the U.S. example), which developed key policies and the new cabinet architecture. In interviews, Jokowi indicated that he would start his presidency with a big bang - a drastic reduction in the very fuel subsidies that a series of his predecessors felt powerless to get rid of.

But Jokowi's publicly displayed self-confidence took severe hits as the new parliament and government were inaugurated in October. Significantly, he was not only under attack from Prabowo's Red-and-White Coalition-he also faced strong pressure from his own alliance to accommodate its many vested interests. In early October, Prabowo's Coalition-which held a majority of the seats in the new parliament—won all available positions in the leadership team of the DPR and the People's Consultative Assembly (Majelis Permusyawaratan Rakyat), strengthening the opposition's bargaining powers vis-à-vis Jokowi's presidency even further. However, while Prabowo subsequently softened his oppositional rhetoric — he even attended Jokowi's inauguration and honoured him with a military salute- the parties in Jokowi's own alliance increasingly tried to force their personnel on him as he formed the new cabinet. Jokowi, who initially had insisted that the appointment of the cabinet was his prerogative, had to remove many of his favourite candidates on Megawati's insistence and replace them with her own loyalists as well as Hanura, PKB, and NasDem functionaries. Thus, compromise choices rather than the maverick operators promised by Jokowi dominated the cabinet announced on 26 October. Tellingly, the line-up included former Army chief of staff Ryamizard Ryacudu, a Megawati protégé and famous for his ultraconservative views on civil-military relations. In short, Indonesia's powerful patronage networks had shown Jokowi that they are alive and well-and willing to defend their interests. Jokowi, in turn, had given an early sign that he was prepared to accommodate at least some of them.

\section{Indonesian democracy in 2014: survival and vulnerability}

Indonesia's 2014 elections were the most important in the history of post-Suharto democracy - and a critical moment only comparable to the 1998 regime change. Neither the 1999 contest between Megawati and Abdurrahman Wahid nor the 2004 and 2009 races between Megawati and Yudhoyono were about the fundamental direction of the country. By contrast, the choice between Jokowi and Prabowo presented Indonesian voters with the option of maintaining the existing democratic polity or sending it on a path of populist experimentation and neo-authoritarian regression. This is despite the fact that Prabowo tried to blur this picture by ambiguously portraying himself as both an autocratic populist intent on challenging the status quo and a democrat committed to the rules of the game. Many

\footnotetext{
${ }^{14}$ Interview with Jokowo Widodo by Marcus Mietzner, 15 September 2014.

15 Interview by Marcus Mietzner with a senior Coalition politician, Jakarta, 11 September 2014.

16 Interview with Jokowo Widodo by Marcus Mietzner, 15 September 2014.
} 
of his voters thought he was the latter, but as the post-election period eloquently demonstrated, his true identity was much closer to the former. In the short term, therefore, Jokowi's victory protected Indonesia from the authoritarian reversal that a Prabowo presidency most likely would have produced - and while more attacks on Indonesian democracy are set to follow, the 2014 elections will remain a strong reminder of the citizenry's determination to defend their democratic rights.

Jokowi's victory also challenges deeply entrenched preconceptions about Indonesian politics and society. First, the rise of a small-town carpenter to the presidency questions the widespread notion that only members of the country's bureaucratic, military and business elite groomed under Suharto's rule can obtain top political positions (Robison and Hadiz 2004; Hadiz 2010). Second, Jokowi's victory over a well-oiled oligarchic machine indicates that the power of oligarchs is not limitless in Indonesia - contrary to increasingly influential claims of oligarchic dominance over the post-Suharto polity (Winters 2011). To be sure, Jokowi had the support of some oligarchs (his vice-president, Jusuf Kalla, for example). But Jokowi's approach to oligarchs has been the same as to other political actors: they were welcome to support him, but must not ask for rewards in return. Indeed, Jokowi's campaign managers were deeply frustrated about his refusal to meet potential donors - many of whom subsequently switched their support to Prabowo, who harboured no such scruples. Third, the polarised nature of the 2014 ballot demonstrates that portrayals of Indonesian elections as inconsequential contests between ideologically indistinguishable members of a huge political cartel (Slater 2004) are overdrawn.

But the 2014 elections also exposed Indonesian democracy's continued vulnerability. The parliamentary polls saw the highest level of vote buying since democratic elections began in 1955, suggesting that Indonesian democracy remains in its early stages of consolidation. And while vote buying was much less prevalent in the presidential elections, other forms of money politics (such as the distribution of cash to local bureaucrats and Islamic clerics who were expected to mobilise voters) were still present. More significantly, the ability of a notorious New Order icon such as Prabowo to gather almost 47 percent of the votes in a presidential election must be a source of concern for supporters of democracy in Indonesia. That many Prabowo voters did not believe they were opting out of democracy does not mitigate this concern - in fact, it emphasises the effectiveness of Prabowo's oligarchic machine politics. Constant pro-Prabowo television coverage (Prabowo dominated five TV stations, Jokowi only one), around-the-clock social media campaigns, and generous spreading of money and other favours made a candidate with a host of human rights problems and character flaws so competitive that he came extraordinarily close to becoming president.

Finally, post-election events have demonstrated that while Prabowo may have lost the 2014 elections, he is determined to further roll back post-1998 reforms and continue his pursuit of the presidency. After Prabowo's successful campaign for the abolition of direct local elections, members of his coalition suggested that they intend to dismantle more laws and regulations passed under democratic rule - including the regime of direct presidential elections. Given Jokowi's vulnerability in the DPR, these announcements carry significant weight. Thus, the survival of Indonesian democracy in the 2014 presidential elections - as important as it was - offers no guarantees for its long-term endurance. 


\section{REFERENCES}

Aria, P. (2013) 'SBY: Kami Ingin Menurunkan Subsidi BBM', Tempo, 8 April. At: http://www.tempo.co/read/news/2013/04/08/090471861/SBY-Kami-Ingin-Menurunkan$\underline{\text { Subsidi-BBM }}$

Aspinall, E. (2014a) 2014. 'Indonesia on the knife's edge', Inside Story (17 June). At: http://inside.org.au/indonesia-on-the-knifes-edge/

Aspinall, E. (2014b) 'Indonesia's 2014 elections: Parliament and patronage', Journal of Democracy 25(4): 96-110.

Aspinall, E and Mietzner, M. (2014a) 'Don't be fooled - Prabowo (still) wants to get rid of direct presidential elections', New Mandala. At: http://asiapacific.anu.edu.au/newmandala/2014/07/02/dont-be-fooled-prabowo-still-wants-to-getrid-of-direct-presidential-elections/

Aspinall, E. and Mietzner, M. (2014b) 'Prabowo's game plan', New Mandala. At: http:/ / asiapacific.anu.edu.au/newmandala/2014/07/10/prabowos-game-plan/

Butt, S. (2012) Corruption and Law in Indonesia, Abingdon: Routledge

Cochrane, J. (2014) 'In Southeast Asia, Indonesia Is an Unlikely Role Model for Democracy', New York Times, 4 September. At: http://www.nytimes.com/2014/09/05/world/asia/in-southeast-asiaindonesia-becomes-a-role-model-for-democracy.html? $\mathrm{r}=1$

Hadiz, V.R. (2010) Localising Power in Post-Authoritarian Indonesia: A Southeast Asia Perspective. Stanford: Stanford University Press.

Hamid, A. (2014) 'Jokowi's Populism in the 2012 Jakarta Gubernatorial Election', Journal of Current Southeast Asian Affairs 33(1): 85-109.

Howes, S. and R. Davies (2014) Survey of Recent Developments, Bulletin of Indonesian Economic Studies, 50:2, 157-183

Indikator Politik Indonesia (2014a) 'Efek Kampanye dan Efek Jokowi: Elektabilitas Partai Jelang Pemilu Legislatif 2014 Temuan Dua Survei Nasional 28 Februari- 10 Maret 201418 - 24 Maret 2014' Jakarta: Indikator Politik Indonesia.

Indikator Politik Indonesia (2014b) 'Hasil Exit Poll Pemilu Presiden RI 2014 Rabu, 9 Juli 2014'. Jakarta: Indikator Politik Indonesia. 
Indo Barometer (2014a) 'Aspirasi Publik Tentang Capres, Cawapres, dan Tiga Skenario 9 Juli 2014'. Jakarta: Indo Barometer.

Indo Barometer (2014b) 'The Final Round: Siapakah Pemenang Pilpres 9 Juli 2014?'. Jakarta: Indo Barometer, p. 24.

Jong, H.N. (2014) 'Prabowo's court Move Backfires', Jakarta Post (15 August). At: http://www.thejakartapost.com/news/2014/08/15/prabowo-s-court-move-backfires.html

McRae, D. (2013) 'Indonesian politics in 2013: The emergence of new leadership?', Bulletin of Indonesian Economic Studies 49(3) 289-304.

Mietzner, M. (2012). 'Ideology, money and dynastic leadership: The Indonesian Democratic Party of Struggle, 1998-2012', South East Asia Research 20(4): 511-531.

Mietzner, M (2014a) 'Indonesia's 2014 elections: Jokowi and how democracy survived', Journal of Democracy 25(4): XXXXXX

Mietzner, M. (2014b) 'Jokowi: Rise of a polite populist', Inside Indonesia, 116 (Apr-Jun). At: http://www.insideindonesia.org/current-edition/jokowi-rise-of-a-polite-populist

Ressa, M. A. (2014) 'Indonesia elections: Prabowo and the divine revelation', AlJazeera, 16 July. Available at: http://m.aljazeera.com/story/20147151443497572

Rinaldi, R. (2014) 'FPI, dan Pemuda Pancasila Deklarasi Dukung Prabowo-Hatta', Tribun News (31 May). At: http://www.tribunnews.com/pemilu-2014/2014/05/31/fpi-fbr-dan-pemuda-pancasiladeklarasi-dukung-prabowo-hatta

Roberts, K. (1995) 'Neoliberalism and the transformation of populism in Latin America: the Peruvian case', World Politics 48(1): 82-116.

Robison, R. and V. R. Hadiz (2004) Reorganizing Power in Indonesia: The Politics of Oligarchy in an Age of Markets. London: RoutledgeCurzon.

Slater, Dan (2004) 'Indonesia's Accountability Trap: Party Cartels and Presidential Power after Democratic Transition,' Indonesia 78: 61-92.

Snyder, J. (2014) 'Campaign finance, strategy and accountability'. New Mandala, 18 July.

SMRC (Saiful Mujani Research and Consulting) (2014a) 'Kinerja Demokrasi dan Pilpres 2014: Evaluasi Pemilih Nasional'. Jakarta: SMRC.

SMRC (Saiful Mujani Research and Consulting) (2014b) 'Koalisi Untuk Calon Presiden: Elite vs. Massa Pemilih Partai, Temuan Survei 20-24 April 2014’ Jakarta: SMRC 
SMRC (Saiful Mujani Research and Consulting) (2014c) 'Survei Nasional Pemilhan Presiden, 30 Juni - 3 Juli 2014'. Jakarta: SMRC.

Sukma, R. (2009) 'Indonesian politics in 2009: Defective elections, resilient democracy', Bulletin of Indonesian Economic Studies (45)3: 317-36.

Triyoga, H. (2014) 'Prabowo: Kalau Ada yang Beri Uang Terima Duitnya, Tapi Tetap Pilih Gerindra', Detiknews (29 March). At: http:/ / news.detik.com/read/2014/03/29/174328/2540628/1562/prabowo-kalau-ada-yang-beriuang-terima-duitnya-tapi-tetap-pilih-gerindra

van Klinken, G. (2014) 'Prabowo and human rights', Inside Indonesia. 116 (Apr-June). At: http://www.insideindonesia.org/current-edition/prabowo-and-human-rights

von Lübke, C. (2014) 'Maverick mayor to presidential hopeful', Inside Indonesia, 115 (Jan-Mar). At: http://www.insideindonesia.org/current-edition/maverick-mayor-to-presidential-hopeful

Weyland, K. (2001) 'Clarifying a contested concept: populism in the study of Latin American politics' Comparative Politics 34(1):1-22.

Winters, J. A. (2011) Oligarchy. New York: Cambridge University Press. 